\title{
Overexpression of microRNA-183 promotes apoptosis of substantia nigra neurons via the inhibition of OSMR in a mouse model of Parkinson's disease
}

\author{
JIN-XIA GAO ${ }^{1 *}$, YU LI $^{2 *}$, SAI-NAN WANG ${ }^{2}$, XING-CHI CHEN ${ }^{2}$, LU-LU LIN ${ }^{2}$ and HUI ZHANG ${ }^{2}$ \\ Departments of ${ }^{1}$ Anesthesiology and ${ }^{2}$ Neurology, The Second Hospital of Dalian Medical University, \\ Dalian, Liaoning 116027, P.R. China
}

Received January 14, 2018; Accepted October 24, 2018

DOI: $10.3892 /$ ijmm.2018.3982

\begin{abstract}
The present study aimed to investigate the effect of microRNA-183 (miR-183) on substantia nigra neurons by targeting oncostatin $\mathrm{M}$ receptor (OSMR) in a mouse model of Parkinson's disease (PD). The positive expression rates of OSMR and the apoptosis of substantia nigra neurons were detected by immunohistochemistry and terminal deoxynucleotidyl transferase-mediated dUTP-biotin nick end-labeling, respectively. Substantia nigra neurons in normal and PD mice were cultured in vitro. The association between miR-183 and OSMR was verified using a dual luciferase reporter gene assay. The expression of miR-183 and the phosphoinositide 3-kinase-Akt signaling pathway-associated genes were detected by reverse transcription-quantitative polymerase chain reaction and western blot analysis, respectively. Cell apoptosis was detected by flow cytometry. OSMR is the target gene of miR-183. The number of OSMR-positive cells and the apoptotic rate of substantia nigra neurons were increased in the PD group. Neurons transfected with miR-183 mimic exhibited elevated expression levels of miR-183, B-cell lymphoma 2 (Bcl-2)-associated $\mathrm{X}$ protein (Bax) and caspase- 9 and increased apoptotic rate, and reduced expression levels of OSMR, Akt, phosphorylated (p-)Akt, glycogen synthase kinase-3 (GSK-3 $\beta$ ), p-GSK-3 $\beta$, Bcl-2, insulin-like growth factor 1 (IGF-1), mammalian target of rapamycin (mTOR) and p-mTOR. The miR-183 inhibitor decreased the expression levels of miR-183, Bax and caspase- 9 and the apoptotic rate; however, increased the expression of OSMR, Akt, p-Akt, GSK-3 $\beta$, p-GSK-3 $\beta$, Bcl-2, IGF-1, mTOR and p-mTOR. The results of
\end{abstract}

Correspondence to: Dr Hui Zhang, Department of Neurology, The Second Hospital of Dalian Medical University, 467 Zhongshan Road, Dalian, Liaoning 116027, P.R. China

E-mail: drzhanghui2017@163.com

*Contributed equally

Key words: microRNA-183, oncostatin M receptor, phosphoinositide 3-kinase-Akt, Parkinson's disease, substantia nigra neurons, apoptosis the present study provide evidence that the overexpression of miR-183 promotes the apoptosis of substantia nigra neurons by inhibiting the expression of OSMR.

\section{Introduction}

Parkinson's disease (PD) is a common neurological disorder and a typical model of striatal dysfunction (1). It is the second most common neurodegenerative disorder, following only Alzheimer's disease in prevalence (2). One of the characteristics of PD is the progressive loss of dopaminergic (DA) neurons in the substantia nigra (3). Patients with PD usually have symptoms of tremor, rigidity and bradykinesia (4). Genetic and environmental factors have been considered in the etiology of PD (5). High frequency deep brain stimulation of the subthalamic nucleus is a popular surgical treatment option; however, it is not applicable to the early stages of PD, and it is not accessible to patients in developing countries (6). Current therapies involving neuroprotective agents, stem cell research, vaccines and various surgical techniques are reported to have limitations (7-9). A previous study investigated pharmacological regimens in treating PD, concluding that further investigations are required to develop superior regimens (10).

MicroRNAs (miRNAs), have been reported to be key in neuronal development, plasticity and disease, including PD (11). The miRNAs are regulators of post-transcriptional genes, with an important influence on neuronal diseases (11). miRNA (miR)-183 belongs to the vertebrate microRNA-183 (miR-183) family (miR-183, miR-96 and miR-182) located on chromosome $7 q 32$ and is dysregulated in numerous types of cancer, including non-small cell lung cancer, breast cancer and colorectal cancer (12-14). The miR-183 family members are reported to control electroreception, photoreception, chemosensation and mechanosensation in vertebrate organs by regulating the majority of ciliated neurosensory epithelial cells (15). It has been reported that the oncostatin $\mathrm{M}$ receptor (OSMR) gene is located on $5 \mathrm{p} 13.1$, the protein of which, OSMR $\beta$, is able to heterodimerize with the interleukin (IL)-6 signal transducer to form type II OSMR $(16,17)$. The phosphoinositide 3-kinase (PI3K) family of lipid kinases have a common biochemical function to phosphorylate phosphoinositide 3-hydroxyl (18). As a serine/threonine kinase, Akt is the central 
regulator of the PI3K pathway, with various downstream mediators that affect key cellular activities; it has a potential mechanistic influence on negative signaling in PD (19). There are previous studies suggesting that the PI3K-Akt signaling pathway is critical in the cell survival, proliferation and growth of neurons (20-22). Activation of the PI3K/Akt/ mTOR pathway correlated with oncogenesis, including glioma, mammary cancer and omophoria (23-25). From the findings described above, there may be certain associations between miR-183, OSMR and the PI3K-Akt signaling pathway in PD. Therefore, the present study was performed to examine how miR-183 is involved in the DA neurons within the substantia nigra pars compacta $(\mathrm{SNc})$ in $\mathrm{PD}$ via the PI3K-Akt signaling pathway.

\section{Materials and methods}

Ethical statement. The experiments and the use of all experimental animals were approved by the Animal Ethics Committee of the Second Hospital of Dalian Medical University (Dalian, China). All efforts were made in the experiments to minimize pain in the mice.

Model establishment and behavioral identification. A total of 60 male C57/BL6 mice of specific-pathogen free grade (aged 10 months and weighing 20-25 g) were supplied by the Laboratory Animal Center of Shanxi Medical University [Shanxi, China; approval no. SCXK (Jin) 20150001]. The mice were housed under controlled conditions $\left(25 \pm 2{ }^{\circ} \mathrm{C}\right.$; humidity of $55 \pm 10 \%$; noise $<60 \mathrm{~dB}$ ) and a $12 \mathrm{~h}$ light/dark cycle $(7 \mathrm{a} . \mathrm{m}$. to 7 p.m.) with free access to food and water. All mice were confirmed to have no abnormalities following 5 days of acclimatized feeding. A total of 50 mice subjected to continuous injection of low-dose 1-methyl-4-phenyl-1,2,3,6-tetrahydropyridine (MPTP) for 6 weeks were randomly selected as the PD group. The other 10 mice, which were subjected to injection of saline, served as the control group. Behavioral alterations of the mice in the normal and PD groups were observed 1, 2, 3, 4, 6 and 8 weeks following model establishment. The mice were placed into a transparent cage $10 \mathrm{~min}$ prior to the assessment to adapt to the environment. The mice were subsequently induced to rotate by a subcutaneous injection of apomorphine $(0.25 \mathrm{mg} / \mathrm{kg}$; cat. no. A14200234234; Tianjin Tianwei Pharmaceutical Co., Ltd., Tianjin, China) into the back. The revolving turns of the mice within 30 min was recorded. When the mice were at a stable average rotating speed of $>5.47 \times 10^{-3} \times \mathrm{g}$, the PD model was considered successfully established (26). After 8 weeks, the normal group and PD group (successful model establishment) were ready for subsequent experiments.

Hematoxylin and eosin (H\&E) staining. Following successful model establishment, the mice were anesthetized with an intraperitoneal injection of pentobarbital sodium $(1 \% ; 50 \mathrm{mg} / \mathrm{kg})$. Following sacrifice by rapid decapitation, their brain tissues were obtained. The substantia nigra of the midbrain was isolated according to the rat brain atlas. The tissues of the substantia nigra were fixed at room temperature in $4 \%$ paraformaldehyde overnight, dehydrated with an ethanol gradient concentration (70, 80, 90, 95 and 100\%; $1 \mathrm{~min} /$ concentration), cleared twice in xylene (5 min/time), and finally embedded in paraffin; parts of the sections were prepared for immunohistochemistry. The tissue blocks were sectioned into $5 \mu \mathrm{m}$ thick sections and placed in an oven at $80^{\circ} \mathrm{C}$ for $1 \mathrm{~h}$. Following cooling, the sections were dehydrated with routine gradient ethanol, cleared in xylene and washed at room temperature. The sections were stained using hematoxylin (cat. no. H8070-5g; Beijing Solarbio Science \& Technology, Co., Ltd., Beijing, China) at room temperature for 4 min and washed with rinsing buffer. Following differentiation with hydrochloric ethanol for $10 \mathrm{sec}$, the sections were washed for $5 \mathrm{~min}$, stained blue with ammonia at room temperature for 10 min, stained with eosin at room temperature (cat. no. PT001; Shanghai Bogoo Biological Technology Co., Ltd., Shanghai, China) for $2 \mathrm{~min}$, dehydrated by gradient ethanol (1 min/concentration), and cleared twice with xylene (1 min/time). The sections were sealed with neutral gum in a draught cupboard, and were placed under a light microscope (magnification, x400; cat. no. DMM-300D; Shanghai Cai Kang Optical Instrument Co., Ltd., Shanghai, China) to observe their pathological features; images were captured to observe their coloration.

Immunohistochemistry. The specimens were fixed in $10 \%$ formaldehyde for 2 weeks at room temperature; they were subsequently placed in $0.01 \mathrm{mmol} 1-1 \mathrm{PBS}$ containing $20 \%$ sucrose. Following specimen sinking, $4 \mu \mathrm{m}$ thick continuous paraffin-embedded sections were produced according to the mouse brain atlas of the SNc. Immunohistochemical staining was performed using the streptavidin-biotin complex (SABC) method. The sections were placed in incubators at $60^{\circ} \mathrm{C}$ for $1 \mathrm{~h}$, dewaxed with conventional xylene, dehydrated with gradient alcohol, and placed in $3 \% \mathrm{H}_{2} \mathrm{O}_{2}$ (Sigma-Aldrich; Merck KGaA, Darmstadt, Germany) for incubation at $37^{\circ} \mathrm{C}$ for $30 \mathrm{~min}$. Following this, the sections were washed with PBS, placed in citrate buffer $(0.01 \mathrm{M})$ and boiled for $20 \mathrm{~min}$ at $95^{\circ} \mathrm{C}$. The sections were subsequently agitated and rinsed three times with $0.01 \mathrm{mmol} / 1 \mathrm{PBS}(\mathrm{pH} 7.4)$. Following inactivation of the endogenous enzyme by $3 \% \mathrm{H}_{2} \mathrm{O}_{2}$, the sections were washed with distilled water three times, blocked with bovine serum albumin (cat. no. SW3015; Beijing Solarbio Science \& Technology Co., Ltd.) for $20 \mathrm{~min}$ at room temperature, cooled to room temperature, and washed with PBS. Subsequently, rabbit anti-mouse OSMR polyclonal antibody (cat. no. ab68476, 1:1,500; Abcam, Cambridge, MA, USA) were added to the sections and incubated at $4^{\circ} \mathrm{C}$ overnight; biotin-labeled secondary antibody immunoglobulin $\mathrm{G}(\mathrm{IgG})$ serum (cat. no. ab6789; 1:1,000; Abcam) was subsequently added for incubation at room temperature for $20 \mathrm{~min}$. Subsequent to washing with PBS three times, the sections were incubated with SABC for $20 \mathrm{~min}$ at room temperature and washed again with PBS four times. The sections were developed with diaminobenzidine (DAB), stained with hematoxylin at room temperature for 3-15 min, dehydrated, cleared, sealed at room temperature and observed under a light microscope. One interpeduncular nucleus section of each mouse in each group was selected. Three fields (magnification, $\mathrm{x} 400$ ) of the selected immunohistochemistry sections with SNc were randomly selected for counting positive cells and paragraphing. Cells stained brown in the cytoplasm and membrane were considered positive cells.

Terminal deoxynucleotidyl transferase (TdT)-mediated dUTP nick labeling (TUNEL) staining. The sections of each 
group were dewaxed with water and blocked with $3 \% \mathrm{H}_{2} \mathrm{O}_{2}$ for $15 \mathrm{~min}$ at room temperature. Following PBS washing, the sections were digested with proteinase $\mathrm{K}\left(37^{\circ} \mathrm{C}\right)$ for $40 \mathrm{~min}$, added to TDT $\left(37^{\circ} \mathrm{C}\right)$ for $1 \mathrm{~h}$ and added to conversion liquid $\left(37^{\circ} \mathrm{C}\right)$ for $30 \mathrm{~min}$. Following washing, the sections were developed with DAB for $3 \mathrm{~min}$. The reaction was terminated when the staining result reached its expected result. Following staining with TUNEL (cat. no. KGA7022; Nanjing Keygen Biotech Co., Ltd., Nanjing, China), apoptotic cells were visible as black or blue/black. The sections were subsequently dried, dehydrated, cleared by xylene and mounted with neutral gum. A total of five discontinuous equidistant interval sections of the substantia nigra nerve tissues were analyzed, and five high-power (magnification, $x 400$ ) visual fields in each section were randomly selected under a fluorescence microscope to observe the expression of TUNEL-positive cells in the substantia nigra neurons of the mice (27).

Cell culture. The PD mice were anesthetized by the intraperitoneal injection of pentobarbital sodium $(1 \%, 50 \mathrm{mg} / \mathrm{kg})$. Following sacrifice via rapid decapitation, substantia nigra tissues were removed under sterile conditions and washed with pre-cooled D-Hank's solution (Beijing Huamaike Biotechnology Co., Ltd.) twice with the meninges and blood vessels stripped. The tissues were cut into smaller segments and added to $5 \mathrm{ml}$ low-glucose Dulbecco's modified Eagle's medium (DMEM; cat. no. SH30021.01; Beijing Solarbio Science \& Technology Co., Ltd.) containing $0.15 \%$ collagenase and transferred into sterile centrifuge tubes. The tissues were digested using a constant-temperature electromagnetic stirrer $\left(37^{\circ} \mathrm{C}\right)$ for $30 \mathrm{~min}$ and centrifuged at $5.48 \mathrm{x} \mathrm{g}$ for $5 \mathrm{~min}$ at room temperature with the supernatant removed. Subsequently, the tissues were added to the appropriate quantity of low-glucose DMEM containing 20\% FBS and centrifuged again at $5.48 \times \mathrm{g}$ and $37^{\circ} \mathrm{C}$; the precipitate was collected and added to the medium to form a cell suspension. The suspension was percussed, mixed and transferred into a disposable culture dish to distribute the precipitate evenly. Following washing with D-Hank's liquid detergent, the precipitate was added with $0.25 \%$ trypsin (containing $0.02 \%$ ethylene diamine tetra acetic acid) and detached for $7-9 \mathrm{~min}$ in the $5 \% \mathrm{CO}_{2}$ incubator at $37^{\circ} \mathrm{C}$. The digestion was terminated by adding culture medium containing $20 \%$ FBS. The cells were subsequently centrifuged at $16.10 \mathrm{x} \mathrm{g}$ for $5 \mathrm{~min}$ at $37^{\circ} \mathrm{C}$ with the supernatant removed. The cells were resuspended with DMEM (20\% FBS), inoculated in a novel dish, and cultured in an incubator $\left(37^{\circ} \mathrm{C} ; 5 \% \mathrm{CO}_{2}\right)$. The medium was replaced every 2-3 days.

Cell grouping and transfection. Normal cells at the third generation were divided into the following groups: Normal group (normal cells without transfection), miR-183 mimic negative control (NC) group (normal cells transfected with $30 \mu \mathrm{g} / 1$ miR-183 mimic NC sequence) and miR-183 mimic group (normal cells transfected with $30 \mu \mathrm{g} / 1 \mathrm{miR}-183$ mimic). PD cells at the third generation were grouped into the following groups: Control group (no transfection), miR-183 inhibitor NC group, miR-183 inhibitor group, OSMR $(0.2 \mu \mathrm{g} / \mathrm{l}$; cells transfected with overexpressed OSMR plasmids) group, insulin-like growth factor 1 (IGF-1) group (cells treated with $20 \mathrm{ng} / \mathrm{ml} \mathrm{IGF-1),}$ miR-183 mimic + IGF-1 group (cells transfected with miR-183 mimic and $20 \mathrm{ng} / \mathrm{ml}$ IGF-1). All plasmids were purchased from Merck KGaA. IGF-1 (Sigma-Aldrich; Merck KGaA), is an activator of the PI3K-Akt signaling pathway. The substantia nigra neurons of the PD and normal mice at the logarithmic growth phase were inoculated in a 6-well plate. When the cell confluence reached $30-50 \%$, cell transfection was performed according to the manufacturer's protocol using Lipofectamine ${ }^{\circledR}$ 2000 (Invitrogen; Thermo Fisher Scientific, Inc., Waltham, MA, USA). Serum-free Opti-Minimum Essential Medium (MEM; $250 \mu \mathrm{l}$; Gibco; Thermo Fisher Scientific, Inc.) was used to dilute the miR-183 mimic, miR-183 inhibitor, OSMR, IGF-1 and miR-183 mimic + IGF-1 groups. The concentration of each group was $100 \mathrm{pmol}$, and the final concentration of the groups was $50 \mathrm{nM}$. Subsequently, the cells were gently mixed and incubated at room temperature for $5 \mathrm{~min}$. Serum-free Opti-MEM ( $250 \mu \mathrm{l}$; Gibco; Thermo Fisher Scientific, Inc.) was used to dilute Lipofectamine ${ }^{\circledR} 2000(5 \mu \mathrm{l})$, and was gently mixed and incubated at room temperature for $5 \mathrm{~min}$. The two diluted mixtures were mixed and incubated for $20 \mathrm{~min}$ at room temperature; finally, $2 \mathrm{ml}$ mixture was added into each cell culture well at a density of $1-2 \times 10^{5}$ cells/well and incubated in a $5 \% \mathrm{CO}_{2}$ incubator at $37^{\circ} \mathrm{C}$ for $6-8 \mathrm{~h}$. Following incubation, the original medium was replaced with a complete medium, and subsequent experiments were performed following culture for 24-48 h.

Dual luciferase reporter assay. The MicroRNA.org database (http://www.microrna.org/) was used to analyze and predict the target gene of miR-183. Target sequences of OSMR-wild-type (WT) 3'untranslated region (UTR) and OSMR-mutant (MUT) 3'UTR were constructed manually and inserted into the pmirGLO reporter plasmid (Promega Corporation, Madison, WI, USA) by double enzyme digestion of the restriction site BamHI/HindIII to obtain the WT and MUT plasmids. The two plasmids were co-transfected with miR-183 mimic and mimic control into 293T cells (Shanghai Zhong Qiao Xin Zhou Biotechnology Co., Ltd., Shanghai, China), using Entraster ${ }^{\mathrm{TM}}$ reagent (Engreen Biosystem Co., Ltd., Beijing, China). At 48 h post transfection, the cells were collected and lysed, and luciferase activity was detected using a Dual-Luciferase Reporter Assay system (cat. no. E1910; Promega Corporation). To the cells, $100 \mu$ l firefly luciferase solution was added to detect the activity of firefly luciferase and $100 \mu \mathrm{l}$ Renilla luciferase solution was added to detect the activity of Renilla luciferase. The relative luciferase activity was calculated. The experiment was repeated three times.

Reverse transcription-quantitative polymerase chain reaction $(R T-q P C R)$ analysis. An RNA extraction kit (cat. no. 10296010; Invitrogen; Thermo Fisher Scientific, Inc.) was used to extract the total RNA from the sample cells. Using an RT kit (cat. no. K1621; Fermentas; Thermo Fisher Scientific, Inc.), the RNA was reverse transcribed into cDNA. The RT system was $10 \mu \mathrm{l}$ and the reaction conditions were as follows: $42^{\circ} \mathrm{C}$ for $30-50 \mathrm{~min}$ (RT reaction) and $85^{\circ} \mathrm{C}$ for $5 \mathrm{sec}$ (reverse transcriptase inactivation). Primers of miR-183, OSMR, Akt, glycogen synthase kinase-3 (GSK-3 $\beta$ ), B-cell lymphoma 2 (Bcl-2), Bcl-2-associated X protein (Bax), caspase-9, IGF-1, mTOR, U6 and GAPDH were designed and synthesized by Takara Biotechnology Co., Ltd. (Dalian, China) (Table I). According to the manufacturer's protocol of the PCR kit (cat. 
Table I. Primer sequences for reverse transcription-quantitative polymerase chain reaction analysis.

\begin{tabular}{ll}
\hline Gene & \multicolumn{1}{c}{ Sequence } \\
\hline miR-183 & F: 5'-TGTAGGACCTCCAGGAGAAGG-3' \\
& R: 5'-TATGGCCCTTCGGTAATTCA-3' \\
U6 & F: 5'-TCCGACGCCGCCATCTCTA-3' \\
& R: 5'-TATCGCACATTAAGCCTCTA-3' \\
OSMR & F: 5'-GCATCCCGAAGCGAAGTCTT-3' \\
& R: 5'-GGGCTGGGACAGTCCATTCTA-3' \\
Akt & F: 5'-ATGAACGACGTAGCCATTGTG-3' \\
& R: 5'-TTGTAGCCAATAAAGGTGCCAT-3' \\
GSK-33 & F: 5'-ATGGCAGCAAGGTAACCACAG-3' \\
& R: 5'-TCTCGGTTCTTAAATCGCTTGTC-3' \\
cas-9 & F: 5'-GGCTGTTAAACCCCTAGACCA-3' \\
& R: 5'-TGACGGGTCCAGCTTCACTA-3' \\
Bcl-2 & F: 5'-GCTACCGTCGTGACTTCGC-3' \\
& R: 5'-CCCCACCGAACTCAAAGAAGG-3' \\
Bax & F: 5'-AGACAGGGGCCTTTTTGCTAC-3' \\
& R: 5'-AATTCGCCGGAGACACTCG-3' \\
IGF-1 & F: 5'-CACATCATGTCGTCTTCACACC-3' \\
& R:5'-GGAAGCAACACTCATCCACAATG-3' \\
mTOR & F: 5'-CAGTTCGCCAGTGGACTGAAG-3' \\
& R:5'-GCTGGTCATAGAAGCGAGTAGAC-3' \\
GAPDH & F: 5'-AGGTCGGTGTGAACGGATTTG-3' \\
& R: 5'-GGGGTCGTTGATGGCAACA-3'
\end{tabular}

miR-183, microRNA-183; F: forward; R, reverse; OSMR, oncostatin $\mathrm{M}$ receptor; GSK-3 $\beta$, glycogen synthase kinase $3 \beta$; cas- 9 , caspase- 9 ; Bcl-2, B-cell lymphoma 2; Bax, Bcl-2-associated X protein; IGF-1, insulin-like growth factor 1; mTOR, mammalian target of rapamycin; GAPDH, glyceraldehyde-3-phosphate dehydrogenase.

no. KR011A1; Tiangen Biotech Co., Ltd., Beijing, China), the RT-qPCR reaction was performed under the following reaction conditions: Pre-denaturation at $95^{\circ} \mathrm{C}$ for $5 \mathrm{~min}, 30$ cycles of denaturation at $95^{\circ} \mathrm{C}$ for $40 \mathrm{sec}$, annealing at $57^{\circ} \mathrm{C}$ for $40 \mathrm{sec}$ at $72^{\circ} \mathrm{C}$ for $40 \mathrm{sec}$, extension at $72^{\circ} \mathrm{C}$ for $10 \mathrm{~min}$ and final extension following cycles at $4^{\circ} \mathrm{C}$ for $5 \mathrm{~min}$. The reaction system included $10 \mu \mathrm{l}$ SYBR Premix Ex Taq ${ }^{\mathrm{TM}}$ II, $0.4 \mu \mathrm{l}$ PCR forward primer $(10 \mu \mathrm{M}), 0.4 \mu \mathrm{l}$ PCR reverse primer $(10 \mu \mathrm{M})$, $2 \mu \mathrm{l}$ DNA template and $7.2 \mu 1$ distilled water. U6 was as an internal reference for the relative expression of miR-183, and GAPDH was as an internal reference for the relative expression of OSMR, Akt, GSK-3 $\beta$, Bax, Bcl-2, caspase-9, IGF-1, and mTOR. The relative quantitative $2^{-\Delta \Delta \mathrm{Cq}}$ method was used to calculate relative mRNA transcription levels of target genes miR-183, OSMR, Akt, GSK-3 $\beta$, Bax, Bcl-2, caspase-9, IGF-1 and mTOR. The calculation was as follows: $\Delta \Delta \mathrm{Cq}=\Delta \Delta \mathrm{Cq}$ PD group $-\Delta \Delta \mathrm{Cq}_{\text {normal group }}, \Delta \mathrm{Cq}=\mathrm{Cq}_{\text {(target genes) }}-\mathrm{Cq}_{\text {(internal references) }}$. The relative mRNA transcription level of target genes was determined as $2^{-\Delta \Delta \mathrm{Cq}}(28)$. The experiment was repeated three times and the mRNA expression levels of genes in each group were compared.
Western blot analysis. The substantia nigra nerve tissues of PD mice $(10 \mathrm{mg})$ and normal mice $(10 \mathrm{mg})$, frozen at $-80^{\circ} \mathrm{C}$, were placed into a glass grinder; the tissue or cell lysate $(500 \mu \mathrm{l}$; cat. no. C1051; Whiga Biosmart Co., Ltd., Guangzhou, China) was added for grinding into a homogenate in the an ice bath. The homogenate was combined with protein lysate for dissociation at $4^{\circ} \mathrm{C}$ for $30 \mathrm{~min}$ (agitation every $10 \mathrm{~min}$ ) and centrifuged at $16.10 \mathrm{x} \mathrm{g}$ for $20 \mathrm{~min}$ at $4^{\circ} \mathrm{C}$, with the lipid layer removed and the supernatant sub-packed. According to the bicinchoninic acid kit (cat. no. 23250; Thermo Fisher Scientific, Inc.), the total protein concentration was detected, and the total protein was packed and placed into a refrigerator at $-80^{\circ} \mathrm{C}$. The protein $(50 \mu \mathrm{g})$ in each group was selected, to which protein denaturants were added (cat. no. 38249090; Sibas Biotechnology Development Co., Ltd., Shanghai, China); the mixture was boiled for $10 \mathrm{~min}$ for degeneration, followed by separation with SDS-PAGE (10\%) and transfer from the gel onto a polyvinylidene fluoride (PVDF) protein gel membrane via the electric transfer method (cat. no. HVLP04700; EMD Millipore, Bedford, MA, USA). The PVDF membrane was blocked in PBST (containing $10 \%$ skim milk powder) at $4^{\circ} \mathrm{C}$ overnight and rinsed with PBST three times (each for $5 \mathrm{~min}$ ). The membrane was subsequently incubated with the following primary antibodies purchased from Abcam: Rabbit anti-mouse OSMR (cat. no. ab172254; 1:1,000), rabbit anti-mouse Akt (cat. no. ab8805; 1:500), rabbit anti-mouse Bax (cat. no. ab32503; 1:1,000), rabbit anti rat Bcl-2 (cat. no. ab32124; 1:1,000), rabbit anti-mouse caspase-9 (cat. no. ab32539; 1:1,000), rabbit anti mouse IGF1 (cat. no. ab39398; 1:100), rabbit anti-mouse mTOR (cat. no. ab2732; 1:2,000) and rabbit anti-mouse GSK-3 $\beta$ (cat. no. ab68476; 1:500) and rabbit anti-mouse GAPDH (cat. no. ab9485; $1: 2,500)$. The membrane was incubated with the antibodies for $2 \mathrm{~h}$ at $37^{\circ} \mathrm{C}$ and subsequently washed with PBST three times, each time for $10 \mathrm{~min}$. Horseradish peroxidase-labeled goat anti-rabbit IgG was subsequently added (cat. no. DF109489; 1:1,000; Yao Yun Biological Technology Co., Ltd., Shanghai, China) and the membrane was incubated for $2 \mathrm{~h}$ at $37^{\circ} \mathrm{C}$, and washed fully with PBST three times (10 min each). An enhanced chemiluminescence kit (cat. no. 36208ES60; Amersham; GE Healthcare Life Sciences, Chalfont, UK) was used for coloration, and ImageJ 1.8.0 gray analysis software (National Institutes of Health, Bethesda, MD, USA) was used for semi-quantitative analysis of the western blot analysis results. GAPDH was used as an internal reference, and the relative protein expression was calculated as the ratio of the gray values of the target band and the reference band. Three repetitions were performed for each sample.

Flow cytometry. At 48 h post-transfection, the cells were detached with trypsin withoutEDTA, collected, and centrifuged (111.8 $\mathrm{x} \mathrm{g}$ for $5 \mathrm{~min}$ ) at room temperature with the supernatant removed. The cells were washed twice with pre-cooled PBS, centrifuged at the same speed for $5 \mathrm{~min}$ at room temperature and the supernatant was removed. An Annexin V-fluorescein isothiocyanate (FITC)/propidium iodide (PI) kit (cat. no. CA1020; Beijing Solarbio Science \& Technology Co., Ltd.) was used for the detection of cell apoptosis. The cells were washed with binding buffer. Annexin-V-FITC and binding buffer were used to prepare intermixtures with a ratio of 1:40 to resuspend cells. Following mixing, the cells were incubated 
A
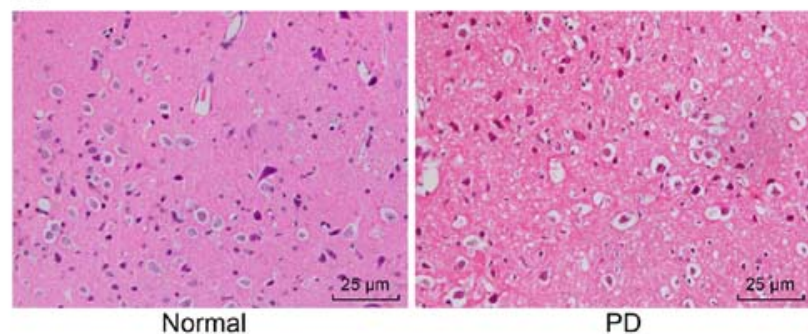

B
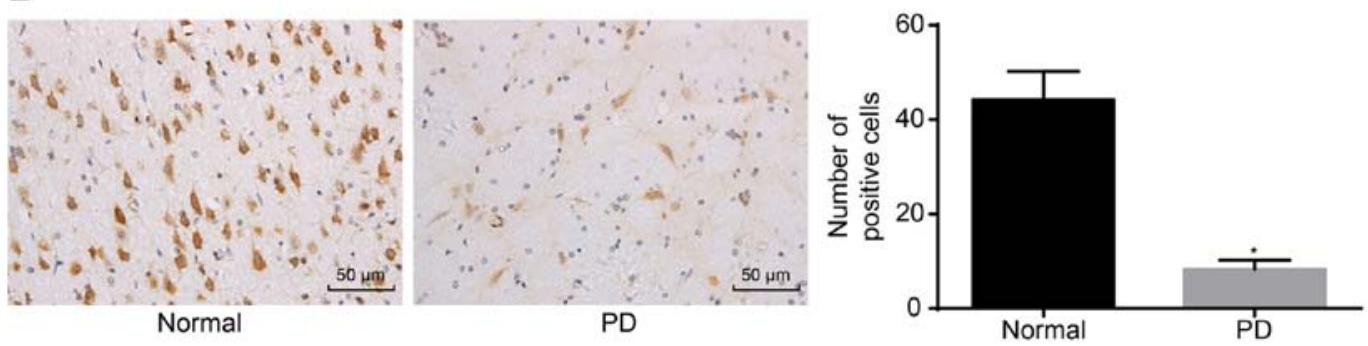

C
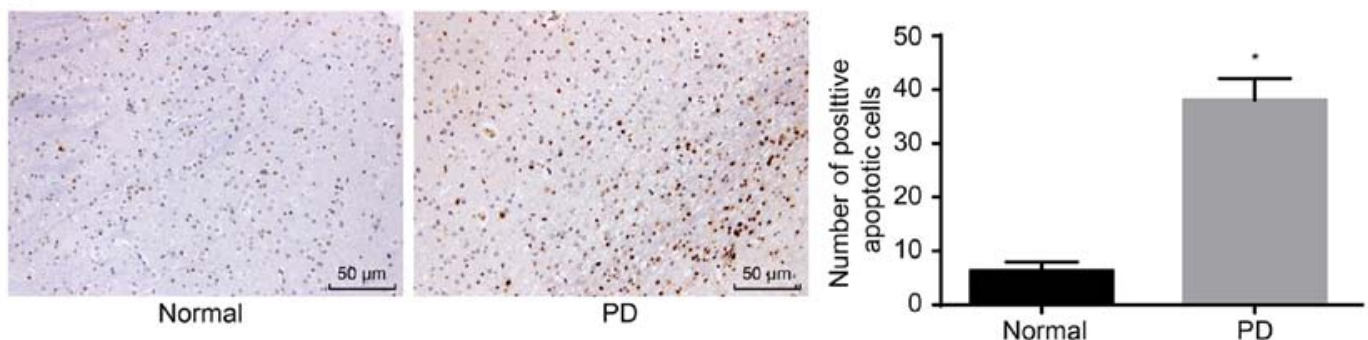

Figure 1. Pathological changes of substantia nigra neurons. (A) H\&E staining of the normal and PD groups (magnification, x400); (B) immunohistochemical detection of the normal and PD groups (magnification, x200); (C) cell apoptosis detected by terminal deoxynucleotidyl transferase-mediated dUTP-biotin nick end-labeling (magnification, $\mathrm{x} 400$ ). ${ }^{*} \mathrm{P}<0.05$, compared with the normal group. H\&E, hematoxylin and eosin; PD, Parkinson's disease.

at room temperature for $30 \mathrm{~min}$. The cells were added to the above intermixture, mixed and incubated at room temperature for $15 \mathrm{~min}$. Apoptosis was detected using the Attune NxT flow cytometer (cat. no. A24864; Thermo Fisher Scientific, Inc.). The experiment was repeated three times.

Statistical analysis. All data were processed with SPSS v21.0 software (IBM Corp., Armonk, NY, USA). Measurement data are presented as the mean \pm standard deviation. Comparisons between two groups were made with an unpaired t-test, and comparisons between groups were analyzed by one-way analysis of variance. The Student-Newman-Keuls method was used as a post hoc test. The experiments were repeated three times. $\mathrm{P}<0.05$ was considered to indicate a statistically significant difference.

\section{Results}

Behavioral changes of mice in the normal and PD groups. Following model establishment, behavioral changes of mice in the normal and PD groups were observed at 1, 2, 3, 4, 6 and 8 weeks. In the PD group, abnormal behaviors, including head deviation, reduced movement, tail stiffness and slow motion were observed at 7-10 days following surgery, whereas no obvious abnormal behavior was observed in the normal group. At the beginning of 2 weeks post-surgery, a number of mice in the experiment were induced to be directionally rotated via APO induction. Following the intraperitoneal injection of APO, a number of mice demonstrated directional rotation within 1-3 min, with a mean time of $2.2 \pm 0.5 \mathrm{~min}$. In the rotation process, the mice mostly rotated with the left hind limb as the fulcrum, bent left in situ counterclockwise rotation end to end, and some even made a reverse circular motion. The number of rotated mice induced by APO increased significantly, and the rotation rate increased. By 6 weeks post-surgery, the number of mice with rotation induced by APO and the rotation rate were stabilized. A total of 35 mice kept rotating, and the mean rotation rate of $>7 \mathrm{r} / \mathrm{min}$ was considered as a successful PD model mouse. Therefore, establishment of the PD model was successful.

Pathological changes of substantianigra neurons. Pathological changes in the substantia nigra neurons were assessed by $\mathrm{H} \% \mathrm{E}$ staining, immunohistochemistry and TUNEL. The H\&E staining demonstrated that the substantia nigra neurons in the normal group had a higher density, larger number, and larger volume, and exhibited elliptical and clear nuclear structures, whereas the substantia nigra neurons in the PD group had decreased numbers, pyknosis, condensation, interstitial edema and visible slender darkly-stained neurons (Fig. 1A). Based on relevant literature, it was identified that OSMR is associated with neurological diseases. It was reported that the knockdown of OSMR increased cerebral infarction size 
A

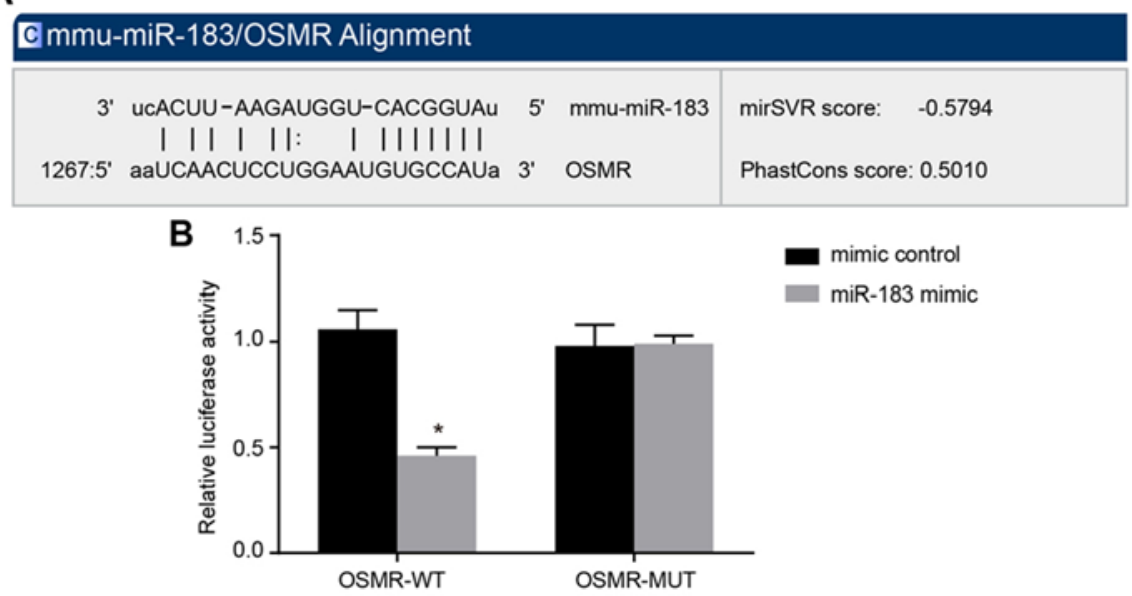

Figure 2. OSMR is the target gene of miR-183. (A) Binding site of miR-183 and OSMR 3'UTR; (B) gene activity detected by a dual luciferase reporter assay; " $\mathrm{P}<0.05$, compared with the mimic control group. miR-183, microRNA-183; OSMR, oncostatin M receptor; WT, wild-type; MUT, mutant.

and weakened nerve function, and that OSMR was induced in normal cells (29). Previous studies suggested that OSMR is a neuroprotective factor that may reduce excitotoxic injury in vivo and in vitro, functioning in the nervous system $(30,31)$. Therefore, the present study aimed to further understand the expression of OSMR in PD mice. Immunohistochemistry used for detecting the expression of OSMR revealed that OSMR-positive cells were yellow or brown, predominantly in the cytoplasm in a conical or elliptical shape. As presented in Fig. 1B, the number of OSMR-positive cells $(44.23 \pm 5.98)$ in the normal group was higher compared with the number of OSMR-positive cells in the PD group $(8.32 \pm 1.89$; $\mathrm{P}<0.05)$. The standard for TUNEL-positive cells is that apoptotic bodies are located in nuclei and appear black or blue/black. Few apoptotic positive substantia nigra neurons were observed in the normal group. TUNEL-positive neurons in substantia nigra were observed in the PD group with a black color, pyknosis, and a round or irregular shape. Compared with the normal group, the PD group had a significantly higher number of apoptotic substantia nigra neurons $(\mathrm{P}<0.05$; Fig. $1 \mathrm{C})$. These results signified that OSMR-positive cells and the apoptotic rate of substantia nigra neurons were elevated in PD.

OSMR is the target gene of miR-183. Furthermore, the present study examined whether miR-183 may directly regulate OSMR by performing online prediction software analysis and luciferase activity determination. Through online prediction software analysis, miR-183 and the OSMR 3'UTR had binding sites (Fig. 2A), and OSMR was identified as the target gene of miR-183. As presented in Fig. 2B, compared with the mimic control group, the luciferase activity intensity of the WT miR-183 mimic group was decreased significantly $(\mathrm{P}<0.05)$, whereas the luciferase activity intensity of the MUT plasmid demonstrated no significant change $(\mathrm{P}>0.05)$. These results suggested that miR-183 inhibits the gene expression of OSMR. These results suggested that miR-183 may directly target OSMR.

Cells transfected with miR-183 inhibitor exhibit decreased expression of miR-183, GSK-3 $\beta$, Bax and caspase-9, and elevated OSMR, Akt, Bcl-2,IGF-1 and mTOR. The PI3K/Akt signaling pathway is key in the development, survival and function of neurons in PD; and Timmons et al (32) reported that the expression of Akt was significantly reduced in the dense part of the substantia nigra of patients with PD. In a PD mouse model induced by 1-methyl-4-phenyl pyridinium cation, the upregulation of regulated in development and DNA damage response 1 , which may inhibit mTOR, accelerated cell death by reducing the mTORC2-dependent phosphorylation of Akt $(33,34)$. One of the pathological hallmarks of PD is progressive and selective loss of DA neurons in the substantia nigra (35). Apoptosis may be the primary reason for the loss of DA neurons in the substantia nigra. Preventing or slowing the apoptosis of DA neurons in the substantia nigra has been a focus of interest in the therapeutics of PD. Matus et al (36), observed that apoptotic neurons in the substantia nigra of patients with PD were significantly increased, further supporting the correlation between apoptosis and the pathogenesis of PD. Based on the above, the present study hypothesized that miR-183 targeting OSMR may be involved in apoptosis through the Akt signaling pathway. Therefore, the expression of miR-183 and the mRNA and protein expression levels of GSK-3 $\beta$, Bax, caspase-9, OSMR, Akt, Bcl-2, IGF-1 and mTOR were determined by RT-qPCR and western blot analysis. No differences in the expression levels of miR-183, OSMR, Akt, p-Akt, GSK-3 $\beta$, p-GSK-3 $\beta$, Bcl-2, IGF-1, mTOR, p-mTOR, Bax, or caspase- 9 were observed between the normal and miR-183 mimic NC groups ( $\mathrm{P}>0.05)$. Compared with the normal group, the miR-183 mimic group exhibited increased expression levels of miR-183, Bax and caspase-9, and decreased expression levels of OSMR, Akt, p-Akt, GSK-3 $\beta$, p-GSK-3 $\beta$, Bcl-2, IGF-1, mTOR and p-mTOR (P<0.05; Fig. 3A-C). Compared with the control group, the miR-183 inhibitor NC group demonstrated no significant differences between the above factors $(\mathrm{P}>0.05)$, whereas the expression of miR-183, Bax and caspase-9 were decreased markedly in the in the miR-183 inhibitor group $(\mathrm{P}<0.05)$, and the expression levels of OSMR, Akt, p-Akt, GSK-3 $\beta$, p-GSK-3 $\beta$, Bcl-2, IGF-1, mTOR and $\mathrm{p}-\mathrm{mTOR}$ were markedly increased $(\mathrm{P}<0.05$; Fig. 4A-C). Compared with the control group, the miR-183 mimic + IGF-1 group exhibited increased expression of miR-183 $(\mathrm{P}<0.05)$ 

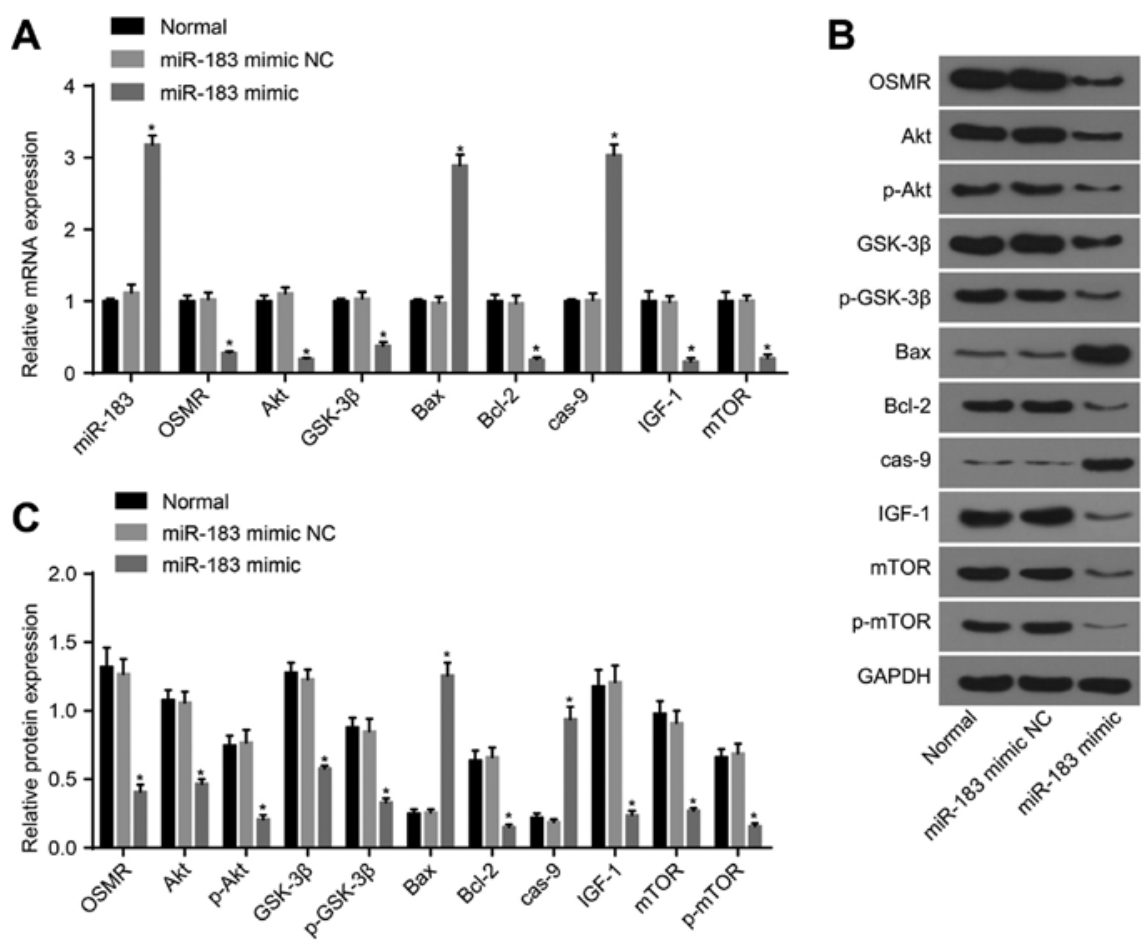

Figure 3. Detection of the expression of miR-183, OSMR and PI3K-Akt pathway-related genes following transfection with miR-183 mimic and mimic NC (A) Expression of miR-183, OSMR and PI3K-Akt pathway-associated genes in the normal, miR-183 mimic NC and miR-183 mimic groups; (B) protein expression of OSMR and PI3K-Akt pathway-related genes among the control, miR-183 mimic NC and miR-183 mimic groups; (C) histogram of protein expression; "P<0.05, compared with the normal group. miR-183, microRNA-183; OSMR, oncostatin M receptor; NC, negative control; IGF-1, insulin-like growth factor 1;

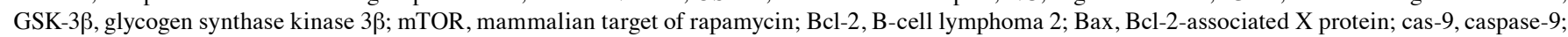
GAPDH, glyceraldehyde-3-phosphate dehydrogenase; p-, phosphorylated.

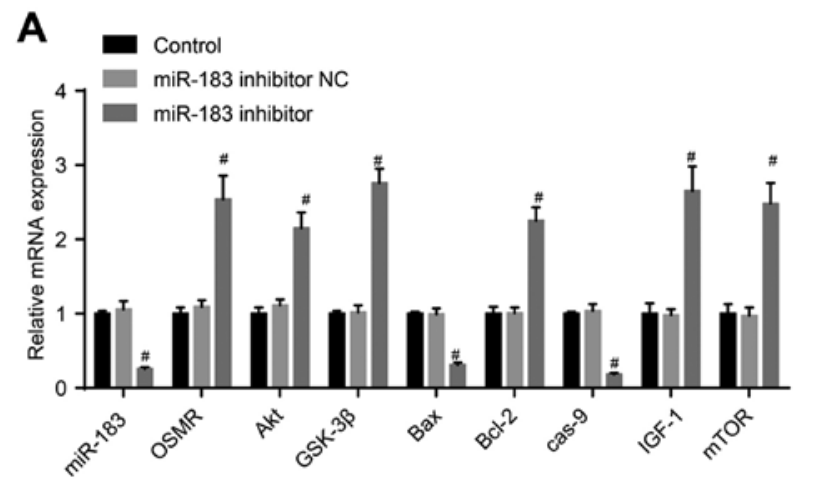

B
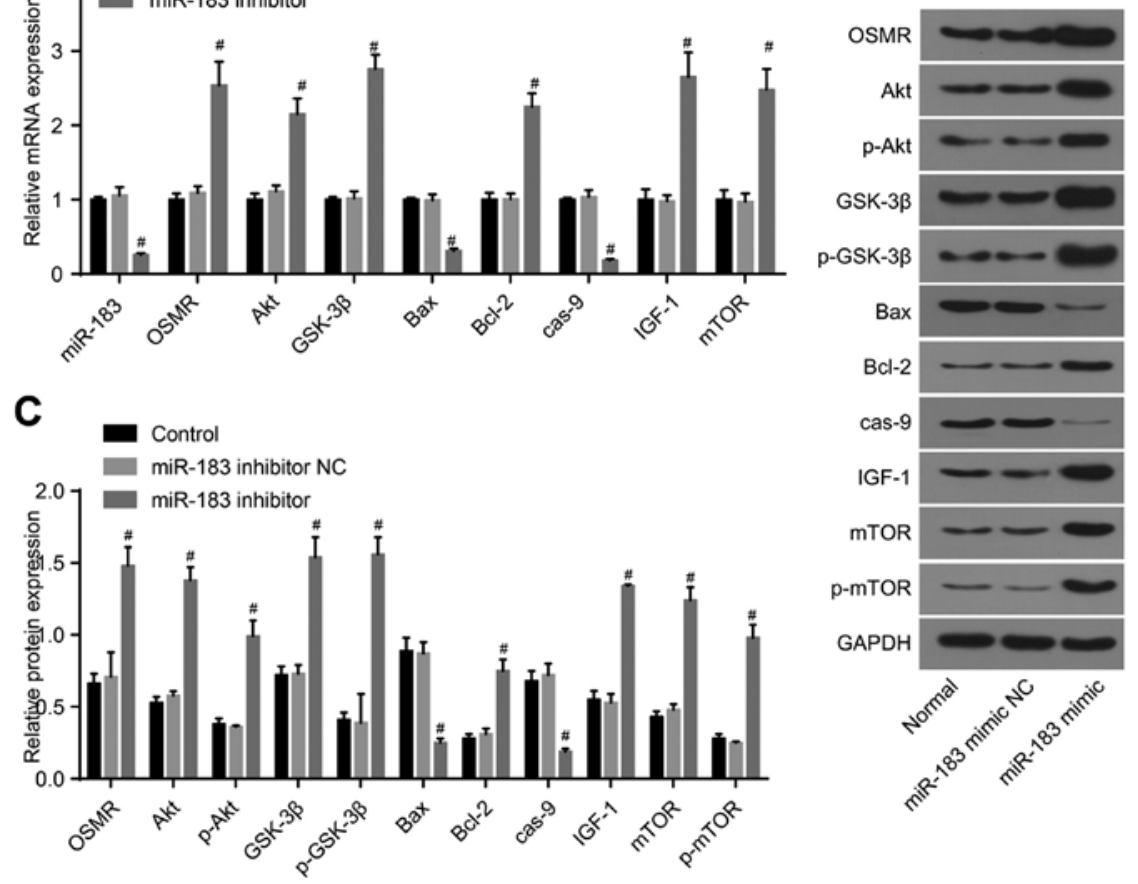

Figure 4. Detection of the expression of miR-183, OSMR and PI3K-Akt pathway-related genes following transfection with miR-183 inhibitor and inhibitor NC. (A) Expression of miR-183, OSMR and PI3K-Akt pathway-related genes in the control, miR-183 inhibitor NC and miR-183 inhibitor groups; (B) protein expression of OSMR and PI3K-Akt pathway-related genes among the control, miR-183 inhibitor NC and miR-183 inhibitor groups; (C) histogram of protein expression. " $\mathrm{P}<0.05$, compared with the control group. miR-183, microRNA-183; OSMR, oncostatin M receptor; NC, negative control; IGF-1, insulin-like

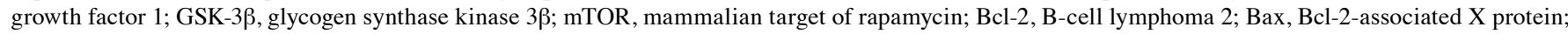
cas-9, caspase-9; GAPDH, glyceraldehyde-3-phosphate dehydrogenase; p-, phosphorylated. 


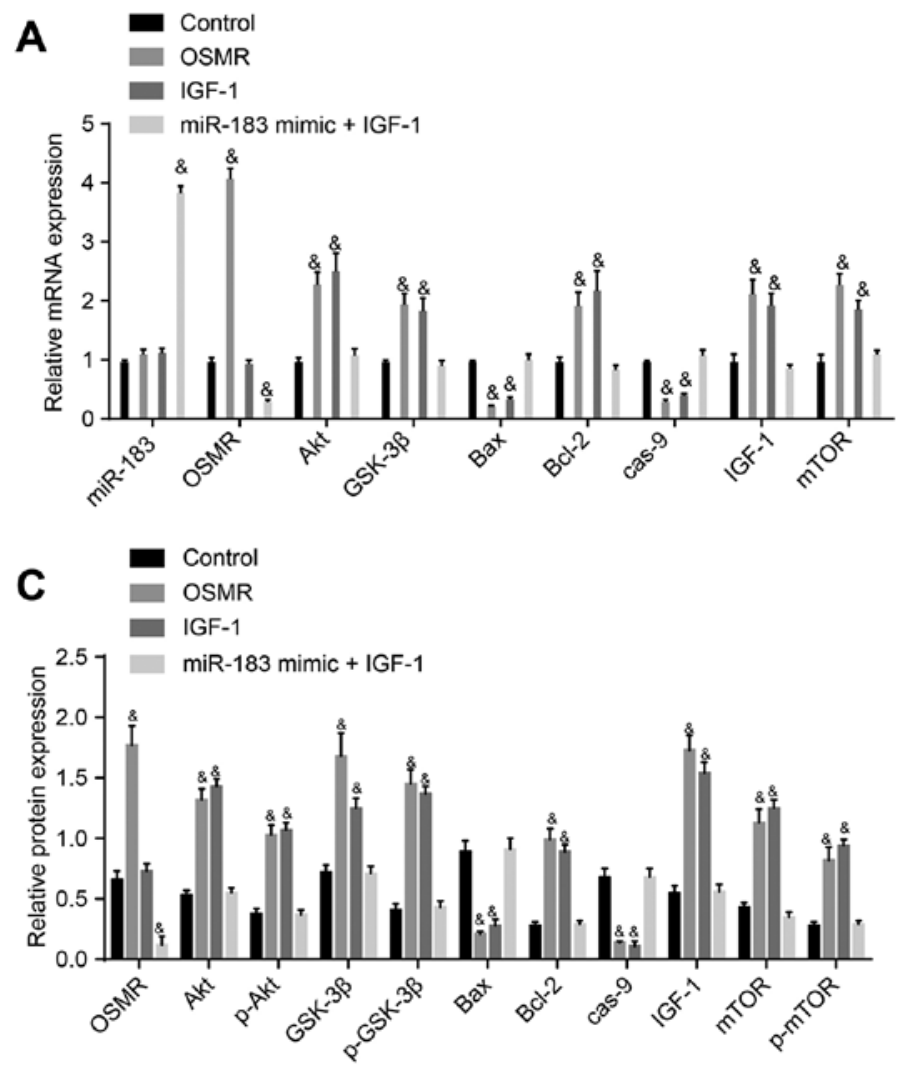

B

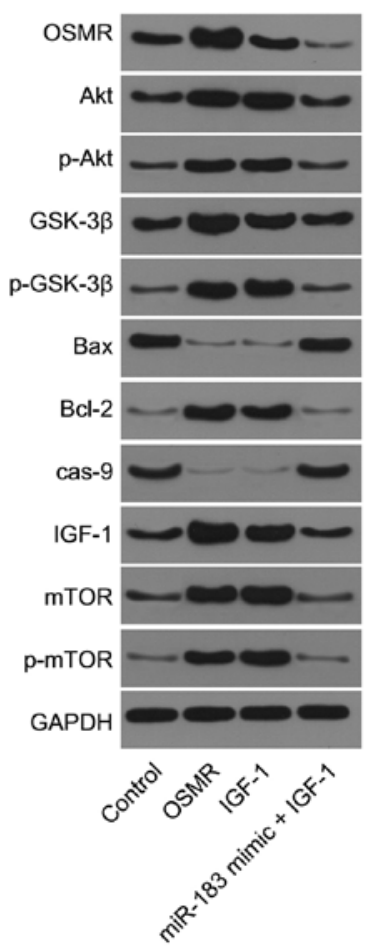

Figure 5. Detection of the expression of miR-183, OSMR and PI3K-Akt pathway-related genes following transfection with OSMR, IGF-1, and miR-183 mimic + IGF-1. (A) Expression of miR-183, OSMR and PI3K-Akt pathway-related genes in the control, OSMR, IGF-1 and miR-183 mimic + IGF-1 groups; (B) protein expression of OSMR and PI3K-Akt pathway-related genes among the control, OSMR, IGF-1 and miR-183 mimic + IGF-1 groups; (C) histogram of protein expression. ${ }^{\&} \mathrm{P}<0.05$, compared with the control group. miR-183, microRNA-183; OSMR, oncostatin M receptor; NC, negative control; IGF-1, insulin-like growth factor 1; GSK-3 $\beta$, glycogen synthase kinase 3 $\beta$; mTOR, mammalian target of rapamycin; Bcl-2, B-cell lymphoma 2; Bax, Bcl-2-associated X protein; cas-9, caspase-9; GAPDH, glyceraldehyde-3-phosphate dehydrogenase; p-, phosphorylated.

and decreased expression of OSMR, whereas no significant differences were identified in the expression of Akt, p-Akt, GSK-3 $\beta$, p-GSK-3 $\beta$, Bcl-2, IGF-1, mTOR, p-mTOR, Bax or caspase-9 $(\mathrm{P}>0.05)$; the OSMR group demonstrated no marked differences in the expression of miR-183 ( $\mathrm{P}>0.05)$; however, demonstrated reduced expression levels of Bax and caspase- 9 , and elevated expression levels of OSMR, Akt, p-Akt, GSK-3 $\beta$, p-GSK-3 $\beta$, Bcl-2, IGF-1, mTOR and p-mTOR $(\mathrm{P}<0.05)$. The expression of miR-183 and OSMR did not differ significantly in the IGF-1 group $(\mathrm{P}>0.05)$, however, the expression levels of Bax and caspase-9 were decreased and those of Akt, p-Akt, GSK-3 $\beta$, p-GSK-3 $\beta$, Bcl-2, IGF-1, mTOR and p-mTOR were increased in the IGF-1 group $(\mathrm{P}<0.05$; Fig. 5A-C). Overall, the obtained results demonstrated that miR-183 inhibited OSMR and the PI3K-Akt signaling pathway, thus promoting neuronal apoptosis in the substantia nigra in mice.

Overexpression of miR-183 decreases cell apoptotic rate. The effects of miR-183 and OSMR on substantia nigra neuron apoptosis were assessed via flow cytometry of Annexin V-FITC/PI double staining. The results (Fig. 6A-C) demonstrated no difference in the apoptotic rate between the normal and miR-183 mimic $\mathrm{NC}$ groups $(\mathrm{P}>0.05)$. Compared with the normal group, the apoptotic rate of the miR-183 mimic group was increased $(\mathrm{P}<0.05)$. No significant difference in the apoptotic rate was observed between the control group and the miR-183 inhibitor
$\mathrm{NC}$ group ( $\mathrm{P}>0.05)$. Compared with the control group, the apoptotic rate of the miR-183 inhibitor group was significantly decreased $(\mathrm{P}<0.05)$. No significant difference in apoptotic rate was observed between the control group and the miR-183 mimic + IGF-1 group $(\mathrm{P}>0.05)$. Compared with the control group, the apoptotic rates in the OSMR and IGF-1 groups were decreased significantly $(\mathrm{P}<0.05)$. These results suggested that miR-183 promotes apoptosis by inhibiting the expression of OSMR and the PI3K-Akt signaling pathway.

\section{Discussion}

PD is a progressive neurodegenerative disease characterized by the loss of DA neurons in the SNc (37). A chronic mechanism of PD is neuroinflammation, which may be associated with the changes in glial cells, including astrocytes and microglia (38). Gene treatment has been demonstrated to be an effective target for treating PD (39). In the present study, it was verified that OSMR is the target gene of miR-183. In addition, it was observed that the overexpression of miR-183 may cause increased apoptotic rates of substantia nigra neurons by inhibiting the expression of OSMR.

First, the present study revealed that PD mice had an elevated expression of miR-183 and decreased expression of OSMR. hsa-miR-183 has been identified to be expressed in PD and has a higher expression compared with in sporadic amyo- 
A
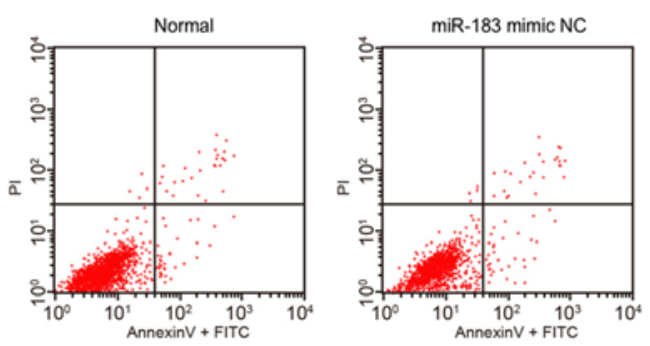

B
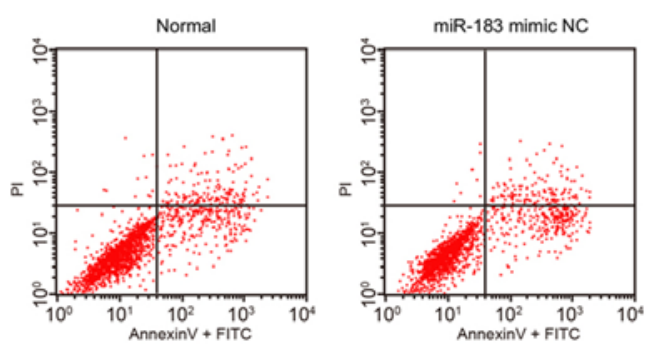
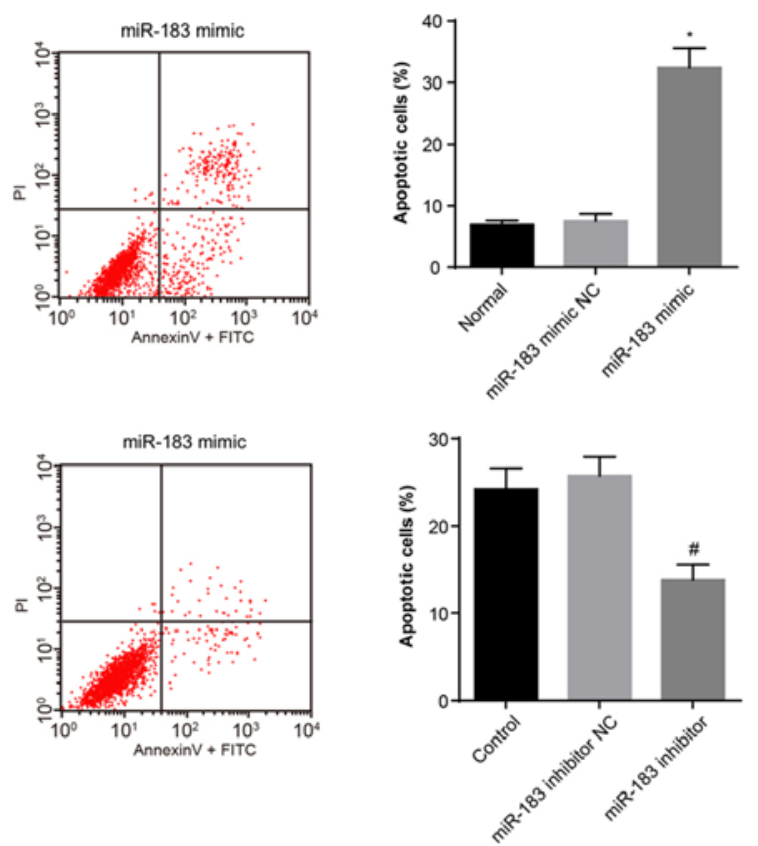

C
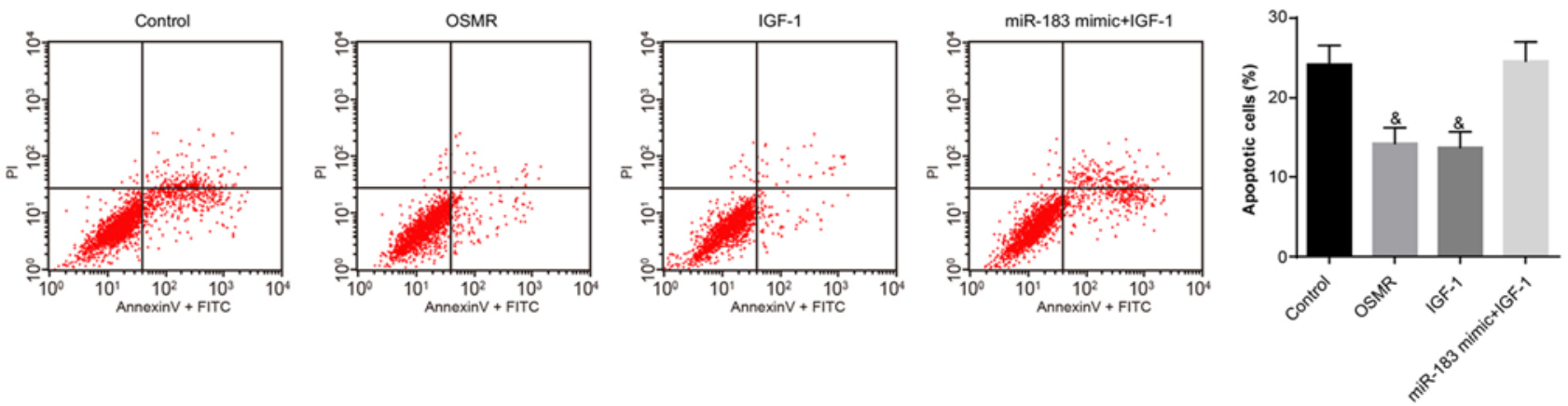

Figure 6. miR-183 promotes apoptosis by inhibiting the expression of OSMR. (A) Apoptosis in the normal, miR-183 mimic NC and miR-183 mimic groups ("P<0.05, compared with the normal group); (B) apoptosis in the control, miR-183 inhibitor NC and miR-183 inhibitor groups ( ${ }^{*} \mathrm{P}<0.05$, compared with the control group); (C) apoptosis in the control, OSMR, IGF-1 and miR-183 mimic + IGF-1 groups ( ${ }^{\circledR} \mathrm{P}<0.05$, compared with the control group). miR-183, microRNA-183; OSMR, oncostatin M receptor; NC, negative control; IGF-1, insulin-like growth factor 1; PI, propidium iodide; FITC, fluoroscein isothiocyanate.

trophic lateral sclerosis (40). Motoyama et al (41) reported the overexpression of miR-183 in human colorectal carcinoma. OSMR, a potent suppressor in tumor cells, is a receptor of OSM, which is a multifunctional cytokine belonging to the IL-6 family $(42,43)$. OSM has been identified to inhibit cell differentiation and apoptosis in cancer (44), and OSMR was observed to induce cell death and apoptosis in adrenocortical Y-1 tumor cells (45). Furthermore, the present study performed a dual luciferase reporter assay and verified that OSMR was the target gene of miR-183.

Second, compared with the blank and NC groups, the expression of miR-183 was higher, whereas the expression levels of Akt, GSK-3 $\beta$, IGF-1 and mTOR were decreased in the substantia nigra neurons in the miR-183 mimic group. Akt is an important molecule in the PI3K/Akt pathway, which provides important signaling for neuroprotection (46). Furthermore, a previous study confirmed that the PI3K/Akt pathway, rather than the mitogen-activated protein kinase/extracellular signal-regulated kinase pathway, significantly contributes to neuroprotection in PD brains (47). GSK-3 $\beta$, as one of the substrates of Akt, is a pleiotropic serine/threonine protein kinase (48). GSK-3 $\beta$ is one of several kinases associated with the posttranslational modifications of key proteins known to be causal in PD (49). IGF-1 is involved in the PI3K/Akt cascades, and its protein synthesis requires the activation of Akt and mTOR (50). IGF-1 may increase the survival and maturation of sympathetic nerve cells, can and promote the development of retinal neurons and the survival of multipolar neurons in the central nervous system $(51,52)$. miR-96 belongs to the miR-183 family, the overexpression of which may cause the suppressed expression of IGF-1 $(53,54)$. mTOR deregulation occurs in human disease (55). The pooled knockdown of the miR-183 cluster has been shown to induce the expression of AKT1 (56). As this was a direct investigation of Akt, follow-up investigations are required with a focus on the association of miR-183 and Akt1/2 in PD. OSMR was significantly downregulated in Janus kinase 1-deficient cells, in which the transient expression of Janus kinase 1 was able to reverse the expression of OSMR (57). Therefore, the present study suggested that miR-183 may inhibit the expression of OSMR and the PI3K/Akt signaling pathway in PD.

Third, in the present study, the miR-183 mimic group exhibited a higher expression of Bax and caspase-9; however, a lower expression of Bcl-2 and mTOR. In addition, decreased 
cell proliferation and increased cell apoptosis were found in the miR-183 mimic group. The Bcl-2 family members have been identified to be anti-apoptotic or pro-apoptotic regulators, with wide effects on cellular activities (58). Bax contains a non-stabilized G8 tract at nucleotides 114-121, which is a member of the Bcl-2 family and has a mutation in mismatch repair-deficient tumors (59). Caspase-9, Bcl-2 and Bax are all closely associated with cell apoptosis. When the protein expression of Bcl-2 is dominant, cells may be prevented from apoptosis, whereas increasing the protein expression of Bax may promote apoptosis (60). Xu et al (61), demonstrated that ginsenoside Re protected from MPTP-induced apoptosis in the PD mouse nigral neurons and may be attributed to increasing the expression of Bcl-2, downregulating the expression of Bax, and inhibiting the activation of caspase-3. Elevated immunoreactivity of the pro-apoptotic protein Bax has been identified in the apoptotic nigral cells of PD (62). Caspase-9 belongs to the caspase family of cysteine proteases, which are involved in apoptosis and cytokine processing (63). A previous study observed that the overexpression of miR-497 may activate caspase-9/3 (64). In addition, Sangawa et al (65) investigated the association between p-caspase- 9 and p-Akt in gastric and colorectal cancer and observed that Akt phosphorylates caspase-9, which may inhibit cell apoptosis. mTOR regulates autophagy, the failure of which leads to deficiency in the elimination of abnormal and toxic protein aggregates, which subsequently triggers cellular stress, failure, and ultimately death (66). Similar to the Bcl-2 family, miR-183 is one of the representative apoptosis-associated miRNA clusters (67). In addition, it was demonstrated that miR-183 activated the reactive oxygen species-mediated apoptotic pathway, which weakened the anticancer effect of temozolomide in treating gliomas (68). Therefore, the overexpression of miR-183 may promote cell apoptosis in PD mice.

The present study concluded that the upregulation of miR-183 may inhibit the expression of OSMR to promote the apoptosis of substantia nigra neurons in PD. In addition, the PI3K/Akt signaling pathway may be involved in this mechanism. However, due to the limitations of time and funding, whether miR-183 mediates other genes associated with apoptosis of substantia nigra neurons via the PI3K/Akt signaling pathway remain unclear. Oussaief et al (69), additionally suggested that the inhibition of Akt upregulated the expression of miR-183. The regulatory association between miR-183 and Akt requires further verified by in vivo interference in the mouse model of PD. The present study may provide clinical reference by using miR-183 inhibitors to restrain the apoptosis of substantia nigra neurons in PD.

\section{Acknowledgements}

Not applicable.

\section{Funding}

No funding was received.

\section{Availability of data and materials}

The datasets used and/or analyzed during the present study are available from the corresponding author on reasonable request.

\section{Authors' contributions}

JXG and YL designed the study. YL, SNW and XCC collated the data, designed and developed the database, and conducted the data analyses. LLL and HZ performed the statistical analysis. YL, SNW and XCC drafted the paper and contributed substantially to its revision. All authors read and approved the final manuscript.

\section{Ethics approval and consent to participate}

The experiments and the use of all experimental animals were approved by the Animal Ethics Committee of the Second Hospital of Dalian Medical University (Dalian, China). All efforts were made in the experiments to minimize pain in the mice.

\section{Patient consent for publication}

Not applicable.

\section{Competing interests}

The authors declare that they have no competing interests.

\section{References}

1. Chong TT, Bonnelle V, Manohar S, Veromann KR, Muhammed K, Tofaris GK, Hu M and Husain M: Dopamine enhances willingness to exert effort for reward in Parkinson's disease. Cortex 69: 40-46, 2015.

2. Lenka A, Padmakumar C and Pal PK: Treatment of older Parkinson's disease. Int Rev Neurobiol 132: 381-405, 2017.

3. Farooqui T and Farooqui AA: Lipid-mediated oxidative stress and inflammation in the pathogenesis of Parkinson's disease. Parkinsons Dis 2011: 247467, 2011.

4. Karunanayaka PR, Lee EY, Lewis MM, Sen S, Eslinger PJ, Yang QX and Huang X: Default mode network differences between rigidity- and tremor-predominant Parkinson's disease. Cortex 81: 239-250, 2016

5. Agim ZS and Cannon JR: Dietary factors in the etiology of Parkinson's disease. BioMed Res Int 2015: 672838, 2015.

6. Benabid AL, Chabardes S, Mitrofanis J and Pollak P: Deep brain stimulation of the subthalamic nucleus for the treatment of Parkinson's disease. Lancet Neurol 8: 67-81, 2009.

7. Gonzales-Portillo GS, Reyes S, Aguirre D, Pabon MM and Borlongan CV: Stem cell therapy for neonatal hypoxic-ischemic encephalopathy. Front Neurol 5: 147, 2014.

8. Kahn E, D'Haese PF, Dawant B, Allen L, Kao C, Charles PD and Konrad P: Deep brain stimulation in early stage Parkinson's disease: operative experience from a prospective randomised clinical trial. J Neurol Neurosurg Psychiatry 83: 164-170, 2012.

9. Scatena R, Martorana GE, Bottoni P, Botta G, Pastore P and Giardina B: An update on pharmacological approaches to neurodegenerative diseases. Expert Opin Investig Drugs 16: 59-72, 2007.

10. Schapira AH, Bezard E, Brotchie J, Calon F, Collingridge GL, Ferger B, Hengerer B, Hirsch E, Jenner $\mathrm{P}$, Le Novère $\mathrm{N}$, et al: Novel pharmacological targets for the treatment of Parkinson's disease. Nat Rev Drug Discov 5: 845-854, 2006.

11. Miñones-Moyano E, Porta S, Escaramís G, Rabionet R, Iraola S, Kagerbauer B, Espinosa-Parrilla Y, Ferrer I, Estivill X and Martí E: MicroRNA profiling of Parkinson's disease brains identifies early downregulation of $\mathrm{miR}-34 \mathrm{~b} / \mathrm{c}$ which modulate mitochondrial function. Hum Mol Genet 20: 3067-3078, 2011.

12. Lowery AJ, Miller N, Dwyer RM and Kerin MJ: Dysregulated miR-183 inhibits migration in breast cancer cells. BMC Cancer 10: 502, 2010

13. Zhu W, Zhou K, Zha Y, Chen D, He J, Ma H, Liu X, Le H and Zhang Y: Diagnostic Value of Serum miR-182, miR-183, miR-210, and miR-126 levels in patients with early-stage non-small cell lung cancer. PLoS One 11: e0153046, 2016. 
14. Yuan D, Li K, Zhu K, Yan R and Dang C: Plasma miR-183 predicts recurrence and prognosis in patients with colorectal cancer. Cancer Biol Ther 16: 268-275, 2015.

15. Pierce ML, Weston MD, Fritzsch B, Gabel HW, Ruvkun G and Soukup GA: MicroRNA-183 family conservation and ciliated neurosensory organ expression. Evol Dev 10: 106-113, 2008.

16. Arita K, South AP, Hans-Filho G, Sakuma TH, Lai-Cheong J, Clements S, Odashiro M, Odashiro DN, Hans-Neto G, Hans NR, et al: Oncostatin $\mathrm{M}$ receptor-beta mutations underlie familial primary localized cutaneous amyloidosis. Am J Hum Genet 82: 73-80, 2008

17. Isozaki O, Tsushima T, Miyakawa M, Emoto N, Demura H, Arai $\mathrm{M}$ and Sato-Nozoe Y: Oncostatin M: a new potent inhibitor of iodine metabolism inhibits thyroid peroxidase gene expression but not DNA synthesis in porcine thyroid cells in culture. Thyroid 7: 71-77, 1997.

18. Markman B, Dienstmann R and Tabernero J: Targeting the $\mathrm{PI}$ KK/Akt/mTOR pathway--beyond rapalogs. Oncotarget 1: 530-543, 2010

19. Zhang W, He H, Song H, Zhao J, Li T, Wu L, Zhang X and Chen J: Neuroprotective effects of salidroside in the MPTP mouse model of Parkinson's disease: Involvement of the PI3K/Akt/GSK3 $\beta$ pathway. Parkinsons Dis 2016: 9450137, 2016.

20. Shao JL, Wan XH, Chen Y, Bi C, Chen HM, Zhong Y, Heng $\mathrm{XH}$, and Qian JQ: H2S protects hippocampal neurons from anoxia-reoxygenation through cAMP-mediated $\mathrm{PI} 3 \mathrm{~K} / \mathrm{Akt} / \mathrm{p} 70 \mathrm{~S} 6 \mathrm{~K}$ cell-survival signaling pathways. Journal of molecular neuroscience: J Mol Neurosci 43: 453-460, 2011.

21. Zhang L, Qu Y, Tang J, Chen D, Fu X, Mao M and Mu D $\mathrm{PI} 3 \mathrm{~K} / \mathrm{Akt}$ signaling pathway is required for neuroprotection of thalidomide on hypoxic-ischemic cortical neurons in vitro. Brain Res 1357: 157-165, 2010.

22. Zhong Z, Wang Y, Guo H, Sagare A, Fernández JA, Bell RD, Barrett TM, Griffin JH, Freeman RS and Zlokovic BV: Protein $S$ protects neurons from excitotoxic injury by activating the TAM receptor Tyro3-phosphatidylinositol 3-kinase-Akt pathway through its sex hormone-binding globulin-like region. J Neurosci 30: 15521-15534, 2010.

23. Choe G, Horvath S, Cloughesy TF, Crosby K, Seligson D, Palotie A, Inge L, Smith BL, Sawyers CL and Mischel PS: Analysis of the phosphatidylinositol 3'-kinase signaling pathway in glioblastoma patients in vivo. Cancer Res 63: 2742-2746, 2003

24. Neve RM, Holbro T and Hynes NE: Distinct roles for phosphoinositide 3-kinase, mitogen-activated protein kinase and p38 MAPK in mediating cell cycle progression of breast cancer cells. Oncogene 21: 4567-4576, 2002.

25. Philp AJ, Campbell IG, Leet C, Vincan E, Rockman SP, Whitehead RH, Thomas RJ and Phillips WA: The phosphatidylinositol 3'-kinase p85alpha gene is an oncogene in human ovarian and colon tumors. Cancer Res 61: 7426-7429,2001.

26. Lee J, Zhu WM, Stanic D, Finkelstein DI, Horne MH, Henderson J, Lawrence AJ, O'Connor L, Tomas D, Drago J, et al: Sprouting of dopamine terminals and altered dopamine release and uptake in Parkinsonian dyskinaesia. Brain 131: 1574-1587, 2008.

27. Lee SY, Moon Y, Hee Choi D, Jin Choi H and Hwang O Particular vulnerability of rat mesencephalic dopaminergic neurons to tetrahydrobiopterin: Relevance to Parkinson's disease. Neurobiol Dis 25: 112-120, 2007.

28. Ayuk SM, Abrahamse H and Houreld NN: The role of photobiomodulation on gene expression of cell adhesion molecules in diabetic wounded fibroblasts in vitro. J Photochem Photobiol B 161: 368-374, 2016

29. Li H, Sen G, Lu Y, Zheng A and Li M: Function and application of type-II oncostatin-M receptor (OSMR) in cerebral apoplexy diseases. CN Patent 104083754A. Filed July 8, 2014; issued October 8, 2018.

30. Weiss TW, Samson AL, Niego B, Daniel PB and Medcalf RL: Oncostatin $M$ is a neuroprotective cytokine that inhibits excitotoxic injury in vitro and in vivo. FASEB J 20: 2369-2371, 2006

31. Pelletier JP and Martel-Pelletier J: Oncostatin M: Foe or friend? Arthritis Rheum 48: 3301-3303, 2003.

32. Timmons S, Coakley MF, Moloney AM and O' Neill C: Akt signal transduction dysfunction in Parkinson's disease. Neurosci Lett 467: 30-35, 2009

33. Malagelada C, Ryu EJ, Biswas SC, Jackson-Lewis V and Greene LA: RTP801 is elevated in Parkinson brain substantia nigral neurons and mediates death in cellular models of Parkinson's disease by a mechanism involving mammalian target of rapamycin inactivation. J Neurosci 26: 9996-10005, 2006.
34. Hsuan SL, Klintworth HM and Xia Z: Basic fibroblast growth factor protects against rotenone-induced dopaminergic cell death through activation of extracellular signal-regulated kinases $1 / 2$ and phosphatidylinositol-3 kinase pathways. J Neurosci 26: 4481-4491, 2006

35. Kwon DH, Kim JM, Oh SH, Jeong HJ, Park SY, Oh ES, Chi JG, Kim YB, Jeon BS and Cho ZH: Seven-Tesla magnetic resonance images of the substantia nigra in Parkinson disease. Ann Neurol 71: 267-277, 2012

36. Matus S, Castillo K and Hetz C: Hormesis: Protecting neurons against cellular stress in Parkinson disease. Autophagy 8: 997-1001, 2012

37. Harms AS, Barnum CJ, Ruhn KA, Varghese S, Treviño I, Blesch A, Tansey MG: Delayed dominant-negative TNF gene therapy halts progressive loss of nigral dopaminergic neurons in a rat model of Parkinson's disease. Mol Ther 19: 46-52, 2011.

38. Jha SK, Jha NK, Kar R, Ambasta RK and Kumar P: p38 MAPK and PI3K/AKT Signalling Cascades inParkinson's Disease. Int J Mol Cell Med 4: 67-86, 2015.

39. LeWitt PA, Rezai AR, Leehey MA, Ojemann SG, Flaherty AW, Eskandar EN, Kostyk SK, Thomas K, Sarkar A, Siddiqui MS, et al: AAV2-GAD gene therapy for advanced Parkinson's disease: a double-blind, sham-surgery controlled, randomised trial. Lancet Neurol 10: 309-319, 2011

40. Chen Y, Wei Q, Chen X, Li C, Cao B, Ou R, Hadano S and Shang HF: Aberration of miRNAs expression in leukocytes from sporadic amyotrophic lateral sclerosis. Front Mol Neurosci 9: 69, 2016.

41. Motoyama K, Inoue H, Takatsuno Y, Tanaka F, Mimori K, Uetake H, Sugihara K and Mori M: Over- and under-expressed microRNAs in human colorectal cancer. Int J Oncol 34: 1069-1075, 2009.

42. Tanaka M, Hirabayashi Y, Sekiguchi T, Inoue T, Katsuki M and Miyajima A: Targeted disruption of oncostatin M receptor results in altered hematopoiesis. Blood 102: 3154-3162, 2003.

43. Hibi K, Goto T, Sakuraba K, Shirahata A, Saito M, Ishibashi K, Kigawa G, Nemoto $\mathrm{H}$ and Sanada Y: Methylation of OSMR gene is frequently observed in non-invasive colorectal cancer. Anticancer Res 31: 1293-1295, 2011.

44. Deng G, Kakar S, Okudiara K, Choi E, Sleisenger MH and Kim YS: Unique methylation pattern of oncostatin $m$ receptor gene in cancers of colorectum and other digestive organs. Clin Cancer Res 15: 1519-1526, 2009.

45. Auernhammer CJ, Dorn F, Vlotides G, Hengge S, Kopp FB, Spoettl G, Cengic N, Engelhardt D and Weber MM: The oncostatin $\mathrm{M}$ receptor/gp130 ligand murine oncostatin $\mathrm{M}$ induces apoptosis in adrenocortical Y-1 tumor cells. J Endocrinol 180: 479-486, 2004

46. Gao Y, Li J, Wu L, Zhou C, Wang Q, Li X, Zhou M and Wang H: Tetrahydrocurcumin provides neuroprotection in rats after traumatic brain injury: Autophagy and the PI3K/AKT pathways as a potential mechanism. J Surg Res 206: 67-76, 2016.

47. Quesada A, Lee BY and Micevych PE: PI3 kinase/Akt activation mediates estrogen and IGF-1 nigral DA neuronal neuroprotection against a unilateral rat model of Parkinson's disease. Dev Neurobiol 68: 632-644, 2008

48. Cross DA, Culbert AA, Chalmers KA, Facci L, Skaper SD and Reith AD: Selective small-molecule inhibitors of glycogen synthase kinase-3 activity protect primary neurones from death. J Neurochem 77: 94-102, 2001.

49. Credle JJ, George JL, Wills J, Duka V, Shah K, Lee YC, Rodriguez O, Simkins T, Winter M, Moechars D, et al: GSK-3 $\beta$ dysregulation contributes to parkinson's-like pathophysiology with associated region-specific phosphorylation and accumulation of tau and $\alpha$-synuclein. Cell Death Differ 22: 838-851, 2015.

50. Bibollet-Bahena O and Almazan G: IGF-1-stimulated protein synthesis in oligodendrocyte progenitors requires $\mathrm{PI} 3 \mathrm{~K} / \mathrm{mTOR} / \mathrm{Akt}$ and MEK/ERK pathways. J Neurochem 109: 1440-1451, 2009.

51. Kouroupi G, Lavdas AA, Gaitanou M, Thomaidou D, Stylianopoulou F and Matsas R: Lentivirus-mediated expression of insulin-like growth factor-I promotes neural stem/precursor cell proliferation and enhances their potential to generate neurons. J Neurochem 115: 460-474, 2010.

52. Hellerstein MK: Relationship between precursor enrichment and ratio of excess M2/excess M1 isotopomer frequencies in a secreted polymer. J Biol Chem 266: 10920-10924, 1991.

53. Li H, Gong Y, Qian H, Chen T, Liu Z, Jiang Z and Wei S: Brain-derived neurotrophic factor is a novel target gene of the has-miR-183/96/182 cluster in retinal pigment epithelial cells following visible light exposure. Mol Med Rep 12: 2793-2799, 2015. 
54. Budzinska M, Owczarz M, Pawlik-Pachucka E, RoszkowskaGancarz M, Slusarczyk P and Puzianowska-Kuznicka M: miR-96, miR-145 and miR-9 expression increases, and IGF-1R and FOXO1 expression decreases in peripheral blood mononuclear cells of aging humans. BMC Geriatr 16: 200, 2016.

55. Laplante $M$ and Sabatini DM: mTOR signaling in growth control and disease. Cell 149: 274-293, 2012.

56. Weeraratne SD, Amani V, Teider N, Pierre-Francois J, Winter D, Kye MJ, Sengupta S, Archer T, Remke M, Bai AH, et al: Pleiotropic effects of miR-183 96 182 converge to regulate cell survival, proliferation and migration in medulloblastoma. Acta Neuropathol 123: 539-552, 2012.

57. Radtke S, Hermanns HM, Haan C, Schmitz-Van De Leur H, Gascan H, Heinrich PC and Behrmann I: Novel role of Janus kinase 1 in the regulation of oncostatin $M$ receptor surface expression. J Biol Chem 277: 11297-11305, 2002.

58. Yamanaka K, Rocchi P, Miyake H, Fazli L, Vessella B, Zangemeister-Wittke $U$ and Gleave ME: A novel antisense oligonucleotide inhibiting several antiapoptotic Bcl-2 family members induces apoptosis and enhances chemosensitivity in androgen-independent human prostate cancer PC3 cells. Mol Cancer Ther 4: 1689-1698, 2005.

59. Zhang L, Yu J, Park BH, Kinzler KW and Vogelstein B: Role of BAX in the apoptotic response to anticancer agents. Science 290: 989-992, 2000

60. Lee JS, Jung WK, Jeong MH, Yoon TR and Kim HK: Sanguinarine induces apoptosis of HT-29 human colon cancer cells via the regulation of $\mathrm{Bax} / \mathrm{Bcl}-2$ ratio and caspase-9-dependent pathway. Int J Toxicol 31: 70-77, 2012.

61. Xu BB, Liu CQ, Gao X, Zhang WQ, Wang SW and Cao YL: Possible mechanisms of the protection of ginsenoside $\mathrm{Re}$ against MPTP-induced apoptosis in substantia nigra neurons of Parkinson's disease mouse model. J Asian Nat Prod Res 7 215-224, 2005

62. Rekha KR and Selvakumar GP: Gene expression regulation of $\mathrm{Bcl} 2$, Bax and cytochrome-C by geraniol on chronic MPTP/probenecid induced C57BL/6 mice model of Parkinson's disease. Chem Biol Interact 217: 57-66, 2014
63. Kuida K: Caspase-9. Int J Biochem Cell Biol 32: 121-124, 2000.

64. Wu R, Tang S, Wang M, Xu X, Yao C and Wang S: microRNA-497 induces apoptosis and suppresses proliferation via the Bcl-2/Bax-caspase9-caspase3 pathway and Cyclin D2 protein in HUVECs. PLoS One 11: e0167052, 2016.

65. Sangawa A, Shintani M, Yamao N and Kamoshida S Phosphorylation status of Akt and caspase-9 in gastric and colorectal carcinomas. Int J Clin Exp Pathol 7: 3312-3317, 2014.

66. Heras-Sandoval D, Pérez-Rojas JM, Hernández-Damián J and Pedraza-Chaverri J: The role of PI3K/AKT/mTOR pathway in the modulation of autophagy and the clearance of protein aggregates in neurodegeneration. Cell Signal 26: 2694-2701, 2014.

67. Papadopoulos EI, Yousef GM and Scorilas A: Cytotoxic activity of sunitinib and everolimus in Caki-1 renal cancer cells is accompanied by modulations in the expression of apoptosis-related microRNA clusters and BCL2 family genes. Biomed Pharmacother 70: 33-40, 2015.

68. Tang H, Bian Y, Tu C, Wang Z, Yu Z, Liu Q, Xu G, Wu M and Li G: The miR-183/96/182 cluster regulates oxidative apoptosis and sensitizes cells to chemotherapy in gliomas. Curr Cancer Drug Targets 13: 221-231, 2013.

69. Oussaief L, Fendri A, Chane-Woon-Ming B, Poirey R, Delecluse HJ, Joab I and Pfeffer S: Modulation of microRNA cluster miR-183-96-182 expression by Epstein-Barr virus latent membrane protein 1. J Virol 89: 12178-12188, 2015.

This work is licensed under a Creative Commons Attribution-NonCommercial-NoDerivatives 4.0 International (CC BY-NC-ND 4.0) License. 